\title{
The Paradox of Incumbency: Patronage, Clientelism, and Incumbent Defeat in Village Chief Elections ${ }^{1}$
}

\author{
Norin Abheseka ${ }^{2}$
}

Received: 23 May 2019 | Accepted: 14 October 2019 | Published: 20 November 2019

\begin{abstract}
This article examines the practices of patronage and clientelism during village elections. Examining Mekarsari Village, Yogyakarta, this study finds that patronage strategies such as programmatic politics, vote buying, club goods, and individual gifts were used by all candidates during village elections owing to the lack of strong social bonds between candidates and voters. The incumbent with all advantages and access to material resources also used patronise and clientelism as strategy, but in fact, it cannot guarantee they win the election. This suggests that the societal relationships and practices of patronage and clientelism continue to affect voter's preference. Applying sociological, psychological, and rational approaches to understanding voter behaviour especially in Java, the study found that, apart from the instrumental and social distance considerations, territorial representation also influenced voter's preference at Village.
\end{abstract}

Keywords: village elections, patronage, clientelism, incumbents, voter behaviour.

\section{Introduction}

Studies of patronage and clientelism as electoral strategies in Indonesia have been widely conducted by academics (Allen, 2015; Aspinall, 2013; Aspinall \& Berenschot, 2019; Fionna, 2014; Mas'Udi \& Kurniawan, 2017; Sukmajati \& Aspinal, 2014; Tans,

\footnotetext{
Research for this article was conducted by the Research Center for Politics and Government (PolGov), Department of Politics and Government, Faculty of Social and Political Sciences, Universitas Gadjah Mada, in conjunction with the Australian National University, Australia, and KITLV, Netherlands. Field research was conducted over the course of one month in ten villages in Bantul, Kulon Progo, and Gunung Kidul Regency, Yogyakarta. The names of informants and locations have been pseudonymised for this article.

2 Research assistant at the Research Centre for Politics and Government (PolGov), Department of Politics and Government, Faculty of Social and Political Sciences, Universitas Gadjah Mada.
} 
2012). However, most of these studies have examined the reciprocal relationships between politicians and voters within executive and legislative elections at the national and regional level. Taking a different perspective, this study examines the practices of patronage and clientelism by candidates, as well as their effect on the electoral performance of incumbents in a Javanese village election. In this study, the authors also consider other factors that shape voters' preferences in Java. It is thus important not only because it offers an understanding of how patronage and clientelism operate at the village level, but also insight into the behaviour of rural voters in Java.

Recently, there has been an interesting phenomenon wherein political practices at the local level have become a favoured research topic among academics, both domestic and foreign. By attaining an understanding of the local, they seek not only to reflect upon the local-level dynamics and complexities of these communities, but also to shed light on the constellation of national politics. One local-level political practice that has drawn researchers' attention is the election of village chiefs, which have been understood as manifestations at the lowest level of government and as part of Indonesia's decentralisation policy (Chen, 2001). In Javanese villages, the election (or selection) of the village chief is an important and almost sacred tradition.

Village chiefs are the leaders and highest formal authorities in the village government system (Tjiptoherijanto \& Prijono, 1983). They rule through a form of paternalistic leadership, one that is created in traditional societies through individual bonds, extended family systems, hierarchies, collectivities, and traditions (Morris \& Pavett, 1992; Pellegrini \& Scandura, 2008). Such paternalistic leadership is often assumed to provide communities with new hopes and with protection (Redding, Norman, \& Schlander, 1994). As such, they are not only leaders, but "fathers", charismatic elders who protect the interests and welfare of their residents and with whom residents can consult or seek guidance (Westwood, 1992). 
The central position of village chiefs has been reaffirmed through Law No. 6 of 2014, which grants village chiefs the authority to manage village finances and assets. Owing to the increasingly strategic and crucial position of village chiefs, the position-once limited to the established elite-has become open to a broader range of candidates. These candidates have not only sought prestige and respect, but also the power wielded by the village "chief" (Wasistiono, 1993). Voters' increased interest in village elections may be seen as indicating the maturation of Indonesia's democracy (Schumpeter, 2010). However, the situation is also concerning; candidates are often willing to win using any means necessary, including paternalistic and clientelistic practices such as vote buying and providing individual gifts.

Such patronage and clientelism may be seen in the 2018 elections in Mekarsari Village, which is located in the southern part of the Special Administrative Region of Yogyakarta. This election was contested by five candidates, including an incumbent who was already serving a six-year term. Ironically, however, despite his advantages - including exposure, networks, and experiencethe incumbent was defeated by a candidate with no previous electoral experience. Heavy competition was also faced by 64 other incumbents who faced re-election in 80 villages in 3 regencies, namely Bantul, Kulon Progo, and Gunung Kidul. Of these, only 26 (40\%) were successful in their bid for re-election.

This study, thus, examines the paternalistic and clientelistic strategies used by candidates as they contested the 2018 election. By doing so, the authors hope to identify the factors that resulted in the incumbent's electoral failure. As its case, this study takes the local election at Mekarsari Village, ${ }^{3}$ Yogyakarta. This village was chosen for two reasons: for candidates' use of patronage and clientelism, and for the incumbent's failure to secure electoral victory.

During the data collection process, the author conducted

A pseudonym. 
intensive observations in the field over the course of a month. Interviews were also conducted with village residents, including the incumbent, village administrators, candidates, campaign team members, previous village chiefs, societal leaders, and ordinary people to guarantee comprehensive data were obtained. Informants were selected using the snowball technique, with the number of informants increasing as new data are required.

This article is divided into six sections. The first provides background information, describing the research topic and method. The second section discusses the concepts of patronage and clientelism within the context of village elections in Java, while the third provides a general overview of Mekarsari Village and its elections. In the fourth section, this article explores the practice of paternalism and clientelism in the election; it is complemented by the fifth section, which discusses other factors that shaped voters' preferences. Finally, the sixth section presents the conclusions of the study.

\section{Patronage, Clientelism, and Voter Behaviour in Village Elections}

Several studies of village elections have shown that the practice of democracy at the lowest level of government (i.e. the village level) cannot be separated from the practice of politics at higher levels (Aspinall \& Rohman, 2017; Halili, 2009; Latif, 2000; Zhao, 2018). Practices such as patronage and clientelism are not purely urban phenomena; they are also found in village chief elections in rural areas, where vote buying and club goods are the most common forms of patronage (Aspinall \& Rohman, 2017; Zhao, 2018). The gifting of money and other goods to voters has become commonplace, and some voters have seen them not as vote buying, but rather as symbols of a social bond (Kana, 2001; Kartodirdjo, 1992; Yuningsih $\&$ Subekti, 2016). As such, the mushrooming of money politics in village elections cannot be blamed solely on candidates and their 
teams, but also on external actors (Halili, 2009).

Patronage, including vote buying ${ }^{4}$ through the provision of individual gifts ${ }^{5}$ and club goods, ${ }^{6}$ has been conducted on a massive scale in elections. Candidates prioritise the improvement of residents' finances, as they perceive the provision of currency and goods as a potent electoral strategy (Zhao, 2018). It is thus not surprising that money politics has become widespread, especially in communities where general education and welfare levels are poor (Jensen \& Justesen, 2014). Meanwhile, according to Wang \& Kurzman (2007), patronage is practiced at the village level by third parties who seek to maximally influence voter preference.

Candidates often have people whom they trust and with whom they are close social ties, including their friends, families, and neighbours (Wang \& Kurzman, 2007), and involve them as intermediary agents in the distribution of money and goods and in the creation of patron-client relations. Through their intermediaries, they interact indirectly with voters.

Figure 1. Pyramid Scheme of Patron-Client Relations

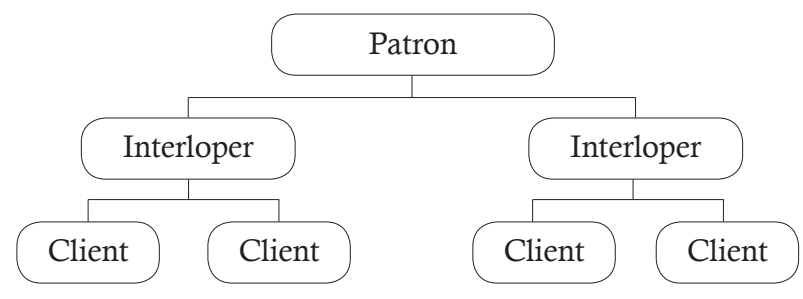

Source: Scott (1972)

4 This article uses the definition of vote buying proposed by Sukmajati and Aspinall (2014), namely candidates' distribution of cash or goods to voters during elections, with the expectation that voters will vote for the candidate in return (Sukmajati \& Aspinal, 2014)

5 This article uses the definition of individual gifts proposed by Sukmajati and Aspinall (2014), namely candidates' gifting of goods (calendars, groceries, foodstuffs, beverages, cigarettes, etc.) to individual voters (Sukmajati \& Aspinal, 2014).

6 This article uses the definition of club good proposed by Sukmajati and Aspinall (2014), namely practices of patronage that involve social groups rather than individuals (Sukmajati \& Aspinal, 2014). 
The practice of patronage and clientelism in village elections depends significantly on voters' social contexts and behaviours. To obtain a better understanding of this practice and of voter behaviour, this study applies three approaches: sociological, psychological, and rational (Bartels, 2010). The sociological approach views social factors such as background (racial, religious, ethnic, regional), status (education, occupation, class), and family traditions as shaping voter preference (Bartels, 2010). The psychological approach, meanwhile, associates voter interest, sense of belonging, and political efficacy as contributing significantly to the shaping of voter behaviour (Mujani \& Liddle, 2012). Finally, the rational approach considers costbenefit analysis and political choice to determine voters' behaviour (Riker \& Ordeshook, 1968).

Within a Javanese context, voter behaviour is strongly influenced by the political preferences of the majority (Sobari, 2016). Often, these preferences are formed through the interactions between voters and political leaders (Gaffar, 1988). Sevtyan et.al (2018) argue that voters in Javanese villages tend to be easily impressed by candidates' promises and public images, even though they are rarely able to evaluate these promises rationally. This gives a considerable advantage to incumbents, as they have already had time to interact with their constituents and establish political networks

Incumbents' involvement in elections at various levels has logical consequences that cannot be ignored in the practice of democracy (Linden, 2004). Incumbents bring their exposure, networks (Cox \& Katz, 1996; Krebs, 1998; Kushner, Siegel, \& Stanwick, 1997), finances (Fouirnaies \& Hall, 2014) and experience (Cox \& Katz, 1996) to their campaigns, all of which other candidates lack. This provides them with significant capital with which they can easily win electoral contestations.

However, several studies have shown that incumbents may also experience electoral defeat, thereby reflecting public evaluation of their performance and policies (Mainwaring \& Torcal, 2006; Uppal, 2009), weak bonds with their constituents, local socio- 
cultural contexts and democratic conditions (Eggers \& Spirling, 2014; Linden, 2004), and shifts in voter mood that-while perhaps insignificant—still influence voters' decisions (Casey, 2012).

\section{The Village Chief Election in Mekarsari}

Mekarsari is a village located in the southern part of the Special Administrative Region of Yogyakarta that participated in the 2018 simultaneous village chief elections. This village, which has a population of approximately 10,000, is divided into 17 pedukuhan (sub-village administrative units) and $103 \mathrm{RT}$ (neighbourhood administrative units). Although half of the village is covered with rice paddies, Mekarsari is not particularly rich in natural resources. Most of the village's revenue ${ }^{7}$ comes from the leasing of village land.

In the past ten years, Mekarsari has experienced increased urban migration as residents have been unable to meet their everyday needs with the resources available in the village and as road conditions have improved. As a result, Mekarsari has transformed from a rural village to a rural fringe village. ${ }^{8}$ Residents commute from the village to the city in order to work or study; this has transformed their way of life. No longer do they earn their income through the agrarian sector; they have become merchants or labourers, or found employment in other regencies. This contrasts significantly with the popular perception of villages as being backwards, subsistent, traditional, and isolated, with a social system built on the foundation of a family system(Soekanto, 2013).

[. . .] yeah, we used to be farmers, but now there are lots of labourers in the field. Now, if we farm, it's something we do samben (on the side). Because people tend to have relatively little land, only about 3,000 square metres. (Dukuh Y interview, 9 October 2018).

In 2018, the village reported a revenue of $\mathrm{Rp} 3,319,641,750$, with contributions as follows: village own-revenue (6\%); village funds (32\%); tax redistribution (4\%); allocation of village funds (50\%); and financial support from the regency government $(8 \%)$.

8 The term rural fringe village is used to refer to villages where land is primarily used for village interests, but whose residents work predominantly outside agriculture. 
Residents have looked forward eagerly to the last three village chief elections (in 2002, 2012, and 2018). These elections are always contested by at least three candidates. Elections are known for incurring significant costs; during the 2002 election, for example, the winning candidate spent at least $\mathrm{Rp} 100,000,000$ to receive the approximately 5,000 votes needed to win. Four years later, the winner of the election spent more than $\mathrm{Rp} 200,000,000$ to receive some 2,500 votes. In 2018 , to receive 3,400 votes, the winning candidate spent between Rp 100,000,000 and Rp 300,000,000. ${ }^{9}$ Even then, the distribution of votes was relatively even (with each candidate receiving between 20 and $30 \%$ of the votes). Not only does this highlight the competitiveness of the village elections, but it also contrasts with postulations by Brien (1994) and Laurence (2005) that poorer regions have less competitive elections. This cannot be separated from the prestige of the position; in order to access this prestige, candidates are willing to spend significant amounts of money.

The 2018 election in Mekarsari was contested by five candidates, namely Eko Santoso, Haryadi, Ali Sasongko, Sukardi, and Purwanto. ${ }^{10}$ Eko Santoso was the incumbent, and the favoured candidate. Having participated in village elections since 2002 (having been pressured to do so by his parents, who wanted their son to become village chief), he was only elected in 2012. His first campaign was unsuccessful, being subverted by the money politics used by Sukardi (the ultimate victor). Learning from his experiences, in 2012 Eko Santoso used money politics to strategically mobilise the village's religious majority and transform it into a political machine. Ultimately, he emerged victorious in the 2012 electionseven though his share of voters was limited by other candidates'

9 These figures were obtained through interviews with candidates and campaign team members.

10 The names of the candidates, actors, and social leaders in this article have been pseudonymised. 
use of money politics. In the 2018 election, Eko Santoso bid for reelection in order to continue his planned economic, education, and health programmes. He did not deny, however, that he also hoped to maintain the prestige that he had enjoyed.

Eko Santoso's performance as village chief between 2012 and 2018 polarised the village residents and administrators. He was publicly perceived as an honest and good man. However, he rarely attended social activities (selamatan, marriages, and funerals), claiming that he did not have to heart to see villagers' deplorable financial conditions. Meanwhile, village administrators considered him a poor leader; village development was sluggish, financial transparency was lacking, and Eko Santoso was not particularly involved in administrative affairs. Furthermore, he was seen as lax in his leadership, thereby giving administrators the opportunity to embezzle funds from the village budget. It is not surprising, thus, that conflict occurred within the village government, reaching a critical point by the end of his term.

The second candidate, Haryadi, was the oldest candidate. Despite having received the backing of religious groups, Haryadi was considered a "bawang gosong"11 in the election. Indeed, in his campaigning he was not enthusiastic, even though such activities were necessary to introduce himself to voters and establish links with them. It was rumoured that he had only run in order to split the voter base of candidates from the same pedukuhan or organisational background.

The third candidate, Ali Sasongko, was the youngest candidate to contest the 2018 election. He used his youth as part of his campaign, claiming that he would bring a spirit of youthful innovation to the village government. He decided to become a candidate owing to his experiences as a member of the Village Consultative Agency (Badan Permusyawaratan Desa, BPD), particularly his dissatisfaction with

11 The term bawang gosong literally translates as 'burnt onion', but means 'underdog' in this context. It was used by one informant to refer to Haryadi and his campaign. 
the lack of transparency. However, he was not seen as a serious contender by the other candidates or by village residents, who saw him as having minimal experience and as being relatively unknown.

The fourth candidate, Sukardi, had served as village chief between 2002 and 2012,12 and was popularly perceived as a strong competitor who could potentially regain his leadership. Sukardi had established good social relations with his constituents during his term as village chief, although he had been plagued by rumours of polygamy towards the end. Furthermore, owing to his father's business activities, Sukardi had access to significant financial capital.

The fifth candidate, who emerged unexpectedly, was Purwanto, a former bank guard who had led a neighbourhood administrative unit for nine years. During his campaign, Purwanto travelled throughout the village to meet and interact with residents. During these activities, Purwanto regularly talked about his grandfather (a former village chief) and his wife (a civil servant with the regency government's Department of Village Empowerment). This was intended to convince voters that, although he had only recently moved to the village, Purwanto had both the capacity and the lineage to become a leader. These efforts were fruitful; Purwanto won the election, receiving 3,449 of the 8,818 valid votes. In this, he defeated the incumbent Eko Santoso (who received 1,996 votes), Sukardi (1,796 votes), Ali Sasongko (1,338 votes), and Haryadi (241 votes). This highlights the dynamics of the village's electoral politics, as most predictions suggested that the incumbent would be re-elected.

The village's election of a new candidate over the incumbent has two important implications: village residents have become increasingly critical in their evaluation of government performance, and transactional politics benefited candidates. Nonetheless, democratic elections were conducted peacefully in Mekarsari.

\footnotetext{
12 Although Sukardi had previously served as a village chief, this article does not classify
} him as an incumbent. 
The spirit of democracy was also strong, with voter participation reaching $82.3 \%$.

\section{Practices of Patronage and Clientelism}

During interviews, three candidates suggested that they had failed because of the winning candidate's use of money politics.

[...] As I understood it, the people were smarter. But it turns out that they were all the same. As such, the strategies stayed the same; cadres and cost politics. The less you spent, the worst you performed. Cost politics were very clear here; had to spend at least Rp. 200,000,000-400,000,000 (Eko Santoso, interview, 16 October 2018).

[...] the one elected was the one who used money. If you didn't spend money, you wouldn't be elected. I sought to get 2,700 votes, but then people's [votes were bought for] Rp 30,000." (Sukardi, interview, 18 October 2018)

Purwanto had worked hard to win the election. As a newcomer to village politics, he had to establish bonds with the people of Mekarsari and introduce himself through various forums, meetings, and activities. He did not arrive empty handed; at every event he attended, he brought snacks, money, and/or political promises.

[...] Purwanto got involved directly in village activities after his candidacy was confirmed. He attended various meetings at the neighbourhood level, as well as other forums, and then asked people what they needed/desired, and then gave them "souvenirs" (goods or money) (Dukuh X, interview, 3 October, 2018)

Aside from becoming directly involved in residents' activities, Purwanto also employed more than 40 cadres-including family members, neighbours, and social leaders. These cadres worked as a unified political machine, visiting neighbourhoods, assessing situations, and mobilising the masses. However, owing to his limited political experience, he and his team experienced a deadlock during their internal discussions. Purwanto insisted that he was unwilling to spend much money, whereas his team insisted that significant expenditures were necessary to win the election. To break the deadlock, six days before the election the campaign team asked 
Sutanto, a local political figure ${ }^{13}$ who was also related to Purwanto, to act as a botoh. ${ }^{14}$ Sutanto agreed, and brought with him some 150 associates. These new cadres campaigned actively, but were accountable only to Sutanto; as a result, it was common for Sutanto to make decisions without the approval of the official campaign team or Purwanto.

As a result, Purwanto's campaign costs increased significantly; Purwanto, his family, and his botoh spent an estimated Rp 100,000,000-300,000,000 on the campaign. For example, cadres were given $\mathrm{Rp} \mathrm{100,000/meeting} \mathrm{to} \mathrm{cover} \mathrm{transportation} \mathrm{costs,} \mathrm{and}$ votes were bought for between $\mathrm{Rp} 30,000$ and $\mathrm{Rp}$ 50,000. Money was also spent on food, witnesses' honorariums, payments for the botoh and his network, and club goods. This figure, however, does not include post-election expenses such as sound system, chair, and tent rentals.

Figure 2. Structure of the Purwanto Campaign Team, Term I

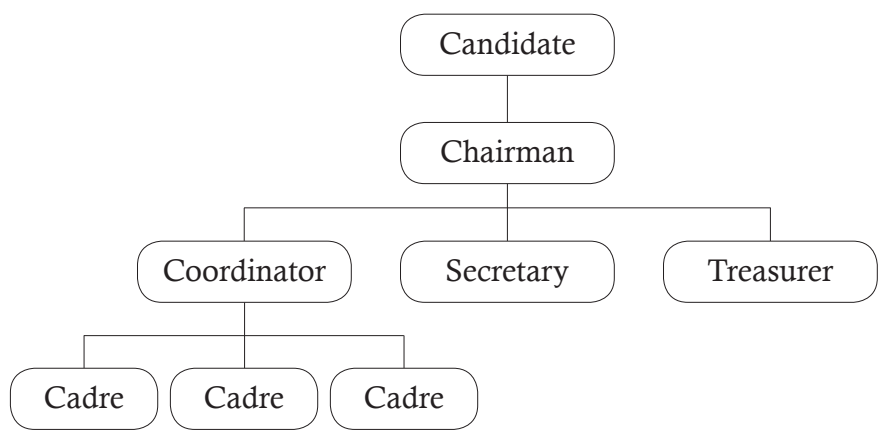

13 Sutanto had not only contested village elections, but also participated in legislative elections. However, he was not successful in either case.

14 The term botoh is given diverse meanings in different villages. In Mekarsari, the word Botoh refers to the stakeholders who provide candidates with financial and strategic support. 
Figure 3. Structure of the Purwanto Campaign Team, Term II

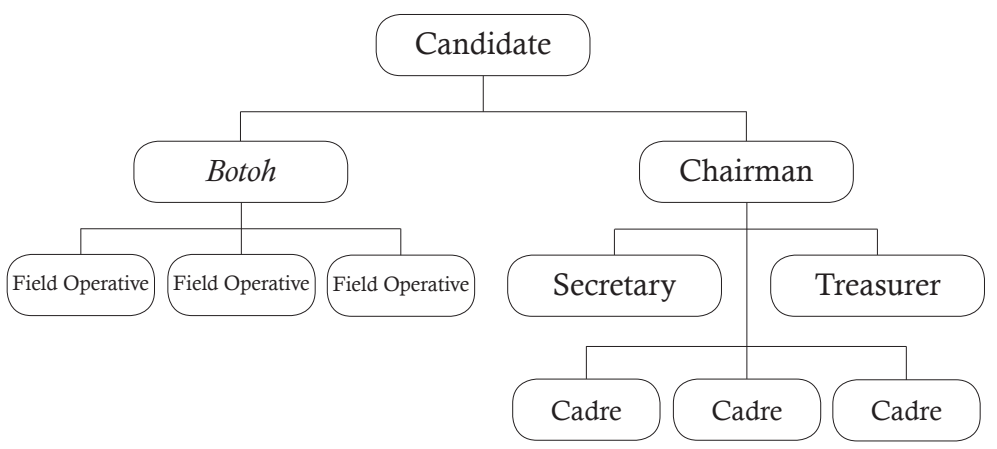

Patronage and clientelism, however, were not only used by Purwanto. These strategies were used by almost all candidates, including the incumbent. He recognised that he enjoyed numerous advantages over his competitors, including exposure. He felt certain that he would emerge victorious, as his constituents had gotten to know him and his work over the past six years. It is not surprising, thus, that during his campaign activities he would regularly discuss his programmes, including those that sought to empower animal husbanders, to reward entrepreneurs, and include his allies in village organisations.

Although this strategy appeared easy, in several communities it proved to be a blunder. As mentioned above, some in the community felt that the incumbent had brought about no significant changes. Furthermore, Eko Santoso had stated that he intended to continue his existing programmes; this did not satisfy voters who desired change.

Eko Santoso had learned much from his failure in 2006 and success in 2012. He continued to rely on his cadres as his vanguard; many of them were the same people as in the previous election - religious leaders, village administrators, and persons with strong emotional bonds. However, he spent less money than in the 
previous election, ${ }^{15}$ as he had limited financial capital and believed that constituents were willing to look at candidates' capacity rather than their willingness to provide financial incentives. As a logical consequence, he hired fewer cadres than in the previous election; he only retained two cadres in all pedukuhan (except for those that were fielding their own candidates) to mobilise voters (see Figure 4). These cadres were expected to gather at least 1,500 votes for Eko Santoso, with individual voters also being provided money to "cover transportation costs" of Rp 20,000/each on election day. This money, according to Eko Santoso, was not intended to buy votes; rather, it was intended to show his appreciation for voters' willingness to take the time to vote. Eko Santoso and his cadres also promised that various goods, including volleyballs, would be distributed after the election. Meanwhile, to express his gratitude for his cadres' outreach efforts, he provided each of them $\mathrm{Rp} 50,000$ per meeting to cover transportation costs.

Eko Santoso also took advantage of his relations with village elites, including administrators and societal leaders, to mobilise voters. He received significant support from village elders. Some did so not out of loyalty, but rather out of a desire to continue manipulating him as a political puppet. Others, meanwhile, sought to repay him for helping them become part of the village elite. However, this strategy was not particularly effective, as some of the elders decided to support other candidates. Those who desired budget transparency tended to support Ali Sasongko, while those who desired firmer leadership tended to support Purwanto.

The incumbent also asked religious leaders to mobilise voters. Owing to his background as an activist, as well as his membership in a religious youth group, he was able to establish close relationships with local religious figures. These religious leaders, as well as their congregations, were amalgamated into a political machine that

15 For the 2012 election, Eko Santoso's team spent Rp 200,000,000 over the course of 100 days. 
backed the incumbent. However, their lack of political experience made it difficult to mobilise voters or campaign for the incumbent, and thus they were ineffectual. Eko Santoso, meanwhile, could not demand that they do better, as their relationship was based solely on kinship networks.

[...] The kyai did not have any strategies that could help condition residents who were no longer involved (in the forums). If he had had a strategy, they could have gone to people's homes, given them business cards. But, no. The religious groups, our political strategies are still limited. For indoctrination, they're willing. Religion requires feeling. But if you link politics (to emotion), nothing will happen. (Eko Santoso, interview, 16 October 2018).

Figure 4. Structure of the Eko Santoso Campaign Team, 2018

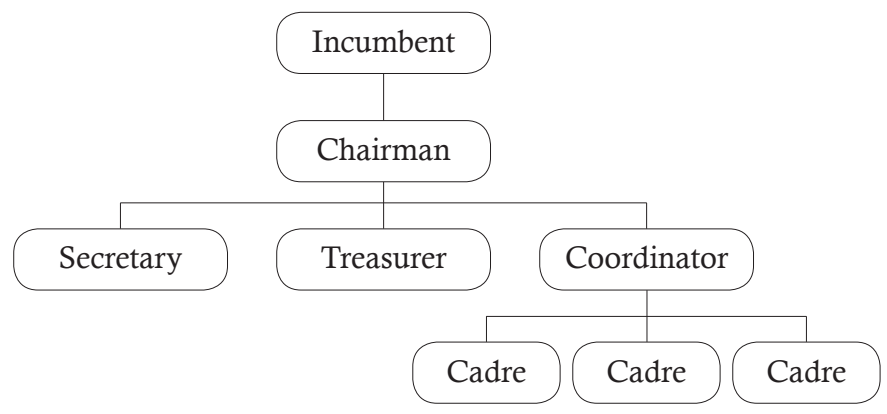

Sukardi, who had twice served as village chief in Mekarsari, used various forms of patronage in the 2018 election. He applied programmatic politics and established clientelistic relations with his volunteers. He sought to establish a simple yet powerful campaign team, with five volunteers in every neighbourhood. He was able to mobilise some 300 volunteers - family, friends, and supporterseach of whom was responsible for approaching constituents and convincing them to vote for Sukardi. These volunteers conducted their campaign activities during community activities, including pengajian (communal prayers). Volunteers recorded the names of 
residents who promised to vote for Sukardi, enabling the campaign team to estimate the number of votes he would receive.

[...] In our structure, we had no chairman, no secretary. All of them received orders directly from me. We had about 300 volunteers. True volunteers, at the pedukuhan and neighbourhood level. They (the volunteers) were not paid. They were my acquaintances, supporters, family. (Sukardi interview, 18 October 2018).

As a consequence of his massive volunteer base, Sukardi had significant expenses. For the operational costs of his 300 volunteers

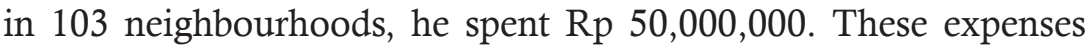
included transportation ( $\mathrm{Rp} 50,000$ per volunteer per meeting), food, shirts, and other campaign propaganda. According to Sukardi, he did not provide any material goods or political promises to volunteers. He believed that his years of experience as village chief and his existing networks, which he had maintained over the years, would convince voters to back him.

From this story, it can be seen, although Sukardi did not admit to giving money to voters, he used programmatic politics to indirectly practice patronage. He also established clientelistic relationships with his volunteers (by reimbursing them for their transportation costs) as well as through his family and friends.

Figure 1. Structure of the Sukardi Campaign Team

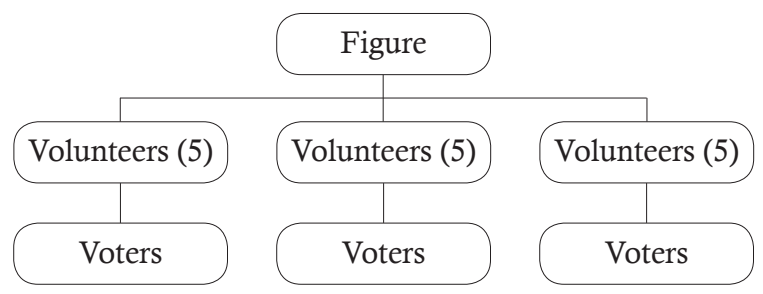

Similarly, Ali Sasongko-who was relatively unknown among the people of Mekarsari-relied on volunteers for his campaign 
activities. Together with his volunteers, Ali Sasongko attempted to mobilise the masses and draw residents' attention to himself and his programmes. In conjunction with his volunteers, Ali Sasongko interacted with constituents, socialised his vision and mission, and made political promises.

Ali Sasongko had between 100 and 200 volunteers, most of whom were youths who shared his vision and mission. His volunteers were not financially motivated, and this mitigated his campaign expenses. Ultimately, Ali Sasongko spent approximately Rp 25,000,000 on his 2018 campaign. Rp 5,000,000 came from his own pocket, and was used for operation costs (food, cigarettes), while volunteers provided $\mathrm{Rp} 20,000,000$ to cover the cost of printing posters, billboards, and stickers. Volunteers did not hesitate to spend money, as they believed that Ali Sasongko could make their shared dreams a reality. The campaign team's structure can be seen below:

Figure 4. Structure of the Ali Sasongko Campaign Team

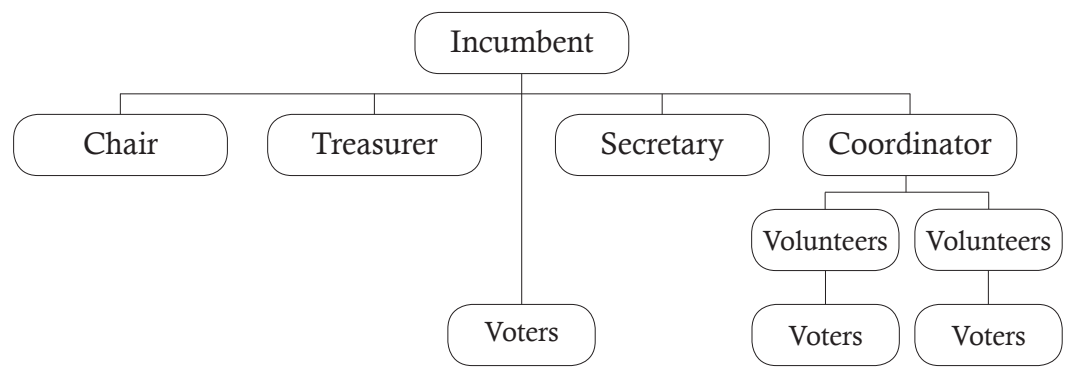

The electoral process in Mekarsari seemingly reinforces mainstream arguments that electoral processes at the village level always involve practices of patronage and clientelism, with money and goods being used as political commodities; wealthy villages may even use their land and other resources as commodities (Tjiptoherijanto \& Prijono, 1983). In Mekarsari, most candidates 
relied on their cadres in their practice of patronage and clientelism.

Interestingly, Purwanto's victory indicates that-even when candidates all used patronage and clientelism as their strategiesvote buying, club goods, individual gifts, programmatic politics, and clientelistic relations with cadres/volunteers/botoh/village elites/ voters were not the only factors that influenced election outcomes. Other factors were involved, as will be discussed below.

\section{Voter Behaviour at the Village Level}

The use of such paternalistic strategies as vote buying, club goods, individual gifts, and programmatic politics did not in and of itself guarantee electoral victory. Various other factors influenced voters' behaviour, including their social, economic, political, and cultural contexts. To understand how voter behaviour is formed, this study applies three approaches: the sociological, psychological, and rational.

The psychological approach views voter behaviour as being informed by voters' interest in politics, sense of belonging, and political efficacy (Saiful Mujani, William R. Liddle, 2012). Within the context of Mekarsari, a sense of belonging to a political party was irrelevant; however, a sense of closeness with the candidate was important. Voters in Mekarsari tended to choose and trust candidates with whom they felt a sense of familiarity. This was particularly prominent in areas that did not field their own candidates. Given this situation, one would assume that the incumbent would be advantaged by his existing networks. However, the incumbent did not become involved in social activities such as volunteer work, slametan, ${ }^{16}$ layatan, ${ }^{17}$ etc. His belief that residents knew him well, and his subsequent decision to not attend their social events, significantly affected his candidacy. Purwanto recognised this, and he and his team

\footnotetext{
16 A slametan is a traditional ceremony used to commemorate certain milestones, including births, marriages, and deaths.

17 In layatan, residents visit the family of a person who recently died and help them cope
} 
intensively used the three months before the election to establish social networks and become involved in communal prayers, layatan, and routine meetings. He visited not only the residents of his own pedukuhan, but also those in pedukuhan that he considered strategic (i.e. those that were not fielding their own candidate). By doing so, Purwanto sought to gather the support of swing voters.

As with the incumbent and Purwanto, Sukardi was well known among the people of Mekarsari. However, his social bonds were relatively weak, as they had been established during his time as village chief. It is thus not surprising that, from a psychological perspective, the incumbent's lack of strong social bonds with his constituents resulted in Purwanto receiving widespread support. The incumbent's failure to establish strong personal relationships with his constituents ultimately resulted in voters making their decisions under the influence of rational or sociological considerations.

In the 2018 Mekarsari village election, the sociological factor that influence voters' preferences and behaviour was the territorial background. Voters tend to support candidates from the same hamlet (or nearest pedukuhan). This tendency is also evident from the results of mapping the distribution of votes received by each candidate, where candidates receive the most votes from their own hamlet and from neighbouring territories (see Illustration 1). It was believed that, by having a local resident serve as village chief, the needs of the pedukuhan would be prioritised. This belief has been maintained in Mekarsari as, under the incumbent, physical development programmes - such as bridge and road constructionhad predominantly been implemented in his pedukuhan of origin. This shows that territorial considerations continued to influence voter preferences, as political leadership could guarantee control of resource distribution. 


\section{Illustration 1}

\section{Distribution of Votes}

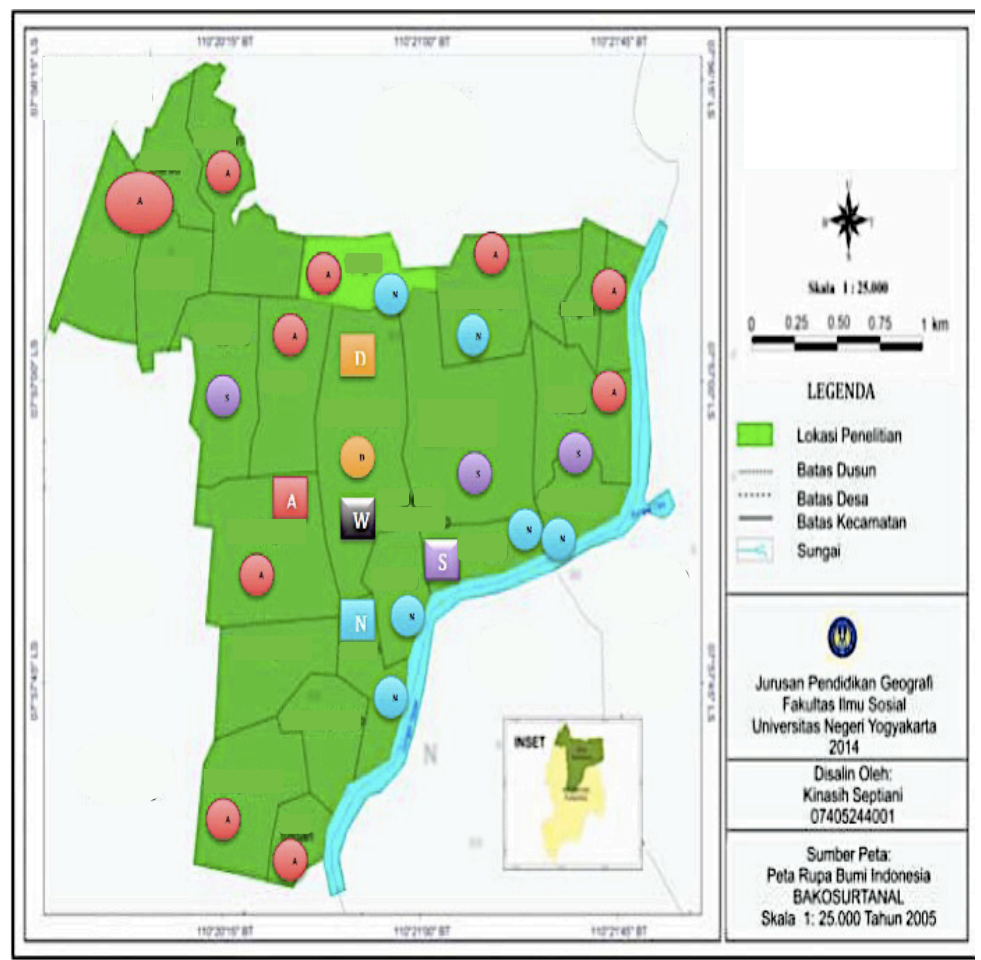

Tabel 1

\begin{tabular}{|c|l|c|l|}
\hline \multicolumn{2}{|l|}{ Area of Electoral Victory } & \multicolumn{2}{l|}{ Area of Origin } \\
\hline & Candidate No. 5 (Purwanto) & $\odot$ & Candidate No. 5 \\
\hline & Candidate No. 4 (Sukardi) & $\odot$ & Candidate No. 4 \\
\hline & Candidate No. 3 (Ali Sasongko) & & Candidate No. 3 \\
\hline & Candidate No. 1 (Eko Santoso) & & Candidate No. 1 \\
\hline & & $\odot$ & Candidate No. 2 \\
\hline
\end{tabular}

The influence of territorial representation on voter behaviour was recognised by candidates and incorporated in their strategies. In Mekarsari, candidates did not campaign intensively in their own 
pedukuhan of origin, as they were certain that they would receive the majority of votes. Similarly, they did not distribute money or goods to the pedukuhan that were fielding their own candidates, as they felt that this would be pointless.

[...] we targeted almost all the pedukuhan. But not over there (Pedukuhan X, Purwanto's area of origin), as they had their own candidate (Ali Sasongko, interview, 16 October 2018).

Ethnic and religious factors, meanwhile, were of limited prominence, all of the candidates share the same religion and organisational affiliations as the majority. The incumbent was able to receive the support of religious leaders easily, but - even though they used religious forums - they proved unable to mobilise their congregations or other village residents. The residents of Mekarsari did not simply follow the instructions of religious leaders, contradicting previous scholars' arguments that Javanese villagers are most strongly influenced by charismatic leadership (Tjiptoherijanto \& Prijono, 1983) and religious affiliations (Gaffar, 1988).

Class status and occupation, similarly, did not significantly influence voters' preferences. Despite being known as a successful merchant, Sukardi was not able to transform it into political capital, as trade does not contribute significantly to the village economy. Similarly, the patron-client relationships that Sukardi was expected to create with his constituents did not emerge. This situation would have been different, however, in a predominantly agrarian village in which the election was being contested by a candidate who owned broad expanses of land.

The lack of strong social cohesion also made it possible for paternalistic and clientelistic practices to occur. Voters lacking any strong personal or territorial affiliations with a particular candidate were more likely to act rationally (i.e. weigh costs and benefits) in making their political decisions. Whichever candidate was willing to make more enticing political promises, and offer more 
significant economic and social benefits, would thus receive these voters' support. This situation can help explain why the incumbent, who used paternalistic and clientelistic strategies in the campaign, ultimately lost; his challengers were able to make better promises and provide better incentives.

\section{Conclusion: Incumbency at the Local Level}

This discussion of the 2018 Mekarsari elections shows that, to some extent, electoral competitions at the village level have become more competitive. This suggests that the practice of democracy in Indonesian society has matured (Schumpeter, 2010). However, in contesting elections, candidates frequently use any means necessary to win; this includes paternalistic and clientelistic strategies.

In Mekarsari, closeness with voters and territorial representation significantly influenced voters' behaviour. This supports the argument that territorial ambitions (together with class and kinship networks) contribute significantly to the shaping of voter behaviour (Haryanto, Sukmajati, \& Lay, 2019). However, when candidates were unable to convert their social bonds with voters into political capital, and when territorial affiliations were non-existent, voters applied a rational approach, weighing costs and benefits before choosing a candidate. In making their decisions, they were influenced by vote buying, club goods, individual gifts, and programmatic politics.

Ironically, the incumbent-who had failed to maintain strong social bonds with constituents during his term - had to rely on paternalistic strategies. Generally, incumbents are seen as being advantaged by their networks, exposure, experience, and access to resources (financial and otherwise) in their search for voter support. However, in Mekarsari, the incumbent relied too heavily on middlemen (his cadres) in his patronage, and voters were unwilling to offer their support as a result. Ultimately, voters were more willing to back Purwanto, who had become personally involved in 
campaign activities and the distribution of club goods despite being a relative newcomer.

The electoral experiences of Mekarsari, it can be sure, differ significantly with those at the regency, city, provincial, or national level, where incumbency is more advantageous as personal closeness and territorial factors become untenable. In villages, which are smaller in area and expect a higher level of intimacy, closeness - both geographic and psychological - significantly affect political contestations. Often, however, incumbents expect that their advantages (their networks, exposure, and experiences) will guarantee victory, and thus do not dedicate themselves to securing their re-election. This offers other candidates the opportunity to approach residents and seduce them with better political promises. 


\section{References}

Allen, N. W. (2015). Clientelism and the personal vote in Indonesia. Electoral Studies. https://doi.org/10.1016/j.electstud.2014.10.005

Aspinall, E. (2013). A Nation In Fragments : Patronage and Neoliberalism in Contemporary Indonesia. Critical Asian Studies. https://doi.org $/ 10.1080 / 14672715.2013 .758820$

Aspinall, E., \& Berenschot, W. (2019). Democracy for Sale: Elections, Clientalism, and the State in Indonesia. In Cornell University Press (Vol. 52). United States of America: Cornell University Press.

Aspinall, E., \& Rohman, N. (2017). Village head elections in Java: Money politics and brokerage in the remaking of Indonesia's rural elite. Journal of Southeast Asian Studies. https://doi.org/10.1017/ S0022463416000461

Bartels, L. M. (2010). The Study of Electoral Behavior. In The Oxford Handbook of American Elections and Political Behavior. Oxford: Oxford University Prss.

Casey, L. (2012). The Role of Money and Incumbency in 2009-2010 State Elections. Retrieved from Followthemoney.org website: https:// www.followthemoney.org/research/institute-reports/the-role-ofmoney-and-incumbency-in-2009-2010-state-elections

Chen, W. (2001). Politics By Other Means: Village Election in China. Journal of East Asian Studies, 1(Perspectives on Environmental Protection in Northeast Asia), 221-241. Retrieved from https:// www.jstor.org/stable/23417762

Cox, G. W., \& Katz, J. N. (1996). Why Did the Incumbency Advantage in U.S. House Elections Grow? American Journal of Political Science. https://doi.org/10.2307/2111633

Eggers, A. C., \& Spirling, A. (2014). The Advantages and Disadvantages of Incumbency: Theory and Evidence from British Elections. Working Paper.

Fionna, U. (2014). Vote Buying in Indonesia's 2014 Election: The Other Side of The Coin. ISEAS Perspective, 35.

Fouirnaies, A., \& Hall, A. B. (2014). The financial incumbency advantage: Causes and consequences. Journal of Politics. https://doi. org/10.1017/S0022381614000139

Gaffar, A. (1988). Javanese voters: A case study of election under a hegemonic party system.

Halili. (2009). Praktik Politik Uang Dalam Pemilihan Kepala Desa: Studi 
di Desa Pakandangan Barat Bluto Sumenep Madura. Jurnal Humaniora, 14, 99-112.

Jensen, P. S., \& Justesen, M. K. (2014). Poverty and vote buying: Surveybased evidence from Africa. Electoral Studies. https://doi. org/10.1016/j.electstud.2013.07.020

Kana, N. L. (2001). Strategi Pengelolaan Persaingan Politik Elit Desa di Wilayah Kecamatan Suruh: Kasus Pemilihan Kepala Desa. Jurnal Renai, 1.

Kartodirdjo, S. (1992). Pesta Demokrasi di Pedesaan : Studi Kasus Pilkades di Jawa Tengah dan DIY. Yogyakarta: Aditya Media.

Krebs, T. B. (1998). The Determinants of Candidates' Vote Share and the Advantages of Incumbency in City Council Elections. American Journal of Political Science, 42(3), 921. https://doi. org/10.2307/2991735

Kushner, J., Siegel, D., \& Stanwick, H. (1997). Ontario Municipal Elections: Voting Trends and Determinants of Electoral Success in a Canadian Province. Canadian Journal of Political Science. https:/ / doi.org/10.1017/s0008423900016000

Linden, L. (2004). Are Incumbents Really Advantaged? The Preference for Non-Incumbents in Indian National Elections.

M. Syahbudin Latif. (2000). Persaingan Calon Kepala Desa di Jawa. Retrieved from https://books.google.co.id/books?hl=id\&lr=\&id=psVuP Ymj2I0C\&oi=fnd\&pg=PA1\&dq=pemilihan+kepala+desa\&ots $=$ ARSY8u3JoB\&sig=p1 fhzswk-di-HzWVow2b-M5led8\&redir $\mathrm{esc}=\mathrm{y} \# \mathrm{v}=$ onepage $\& \mathrm{q} \& \mathrm{f}=$ false

Mainwaring, S., \& Torcal, M. (2006). Party System Institutionalization and Party System Theory After The Third Wave of Democratization. In Handbook of Party Politics (pp. 204-227). Sage Publications.

Mas'Udi, W., \& Kurniawan, N. I. (2017). Programmatic politics and voter preferences: The 2017 election in Kulon Progo, Yogyakarta. Contemporary Southeast Asia, 5. https://doi.org/10.1355/cs39-3c

Morris, T., \& Pavett, C. M. (1992). Management Style and Productivity in Two Cultures. Journal of International Business Studies. https://doi. org/10.1057/palgrave.jibs.8490264

Pellegrini, E. K., \& Scandura, T. A. (2008). Paternalistic leadership: A review and agenda for future research. Journal of Management. https://doi.org/10.1177/0149206308316063

Redding, S. G., Norman, A., \& Schlander, A. (1994). The nature of individual attachment to the organization: A review of East Asian 
variations. In Handbook of industrial and organizational psychology, Vol. 4.

Riker, W. H., \& Ordeshook, P. C. (1968). A Theory of the Calculus of Voting. American Political Science Review. https://doi.org/10.1017/ S000305540011562X

Saiful Mujani, William R. Liddle, and K. A. (2012). Kuasa Rakyat Analisis Tentang Perilaku Memilih dalam Pemilihan Legislatif dan Presiden Indonesia Pasca Orde Baru. https://doi.org/10.13185/st2014.02206

Schumpeter, J. A. (2010). Capitalism, socialismand democracy. In Capitalism, Socialism and Democracy. https://doi.org/10.4324/9780203857090

Sevtyan, A., Sobari, W., \& Mochtar, H. (2018). Perilaku Gumunan: Memperluas Kajian Perilaku Pemilih Jawa. POLITICO. https:// doi.org/10.32528/politico.v18i2.1655

Sobari, W. (2016). Anut Grubyuk in the Voting Process: The Neglected Explanation of Javanese Voters (Preliminary Findings). Southeast Asian Studies. https://doi.org/10.20495/seas.5.2

Soekanto, S. (2013). Sosiologi Suatu Pengantar. Jakarta: PT. Raja Grafindo Hasada.

Sukmajati, M., \& Aspinal, E. E. (2014). Politik Uang di Indonesia: Patronase dan Klientelism di Pemilu Legislatif 2014. In E. Aspinall \& M. (eds) Sukmajati (Eds.), Polgov: Yogyakarta (1st ed.). Yogyakarta: Penerbit PolGov.

Tans, R. (2012). Mobilizing Resources, Building Coalitions: Local Power in Indonesia. Policy Studies. https://doi.org/10.21506/j. ponte.2016.10.28

Tjiptoherijanto, P., \& Prijono, Y. M. (1983). Demokrasi di Pedesaan Jawa. Jakarta: Penerbit Sinar Harapan.

Uppal, Y. (2009). The Disadvantaged Incumbents: Estimating Incumbency Effects in Indian State Legislatures. In Public Choice. https://doi. org/10.1007/s11127-008-9336-4

Wang, C.-S., \& Kurzman, C. (2007). The Logistics: How to Buy Votes. Elections for Sale: The Causes and Consequences of Vote Buying. https:// doi.org/10.1016/j.electstud.2013.11.006

Wasistiono, S. (1993). Kepala Desa dan Dinamika Pemilihannya. Bandung: Penerbit Mekar Rahayu.

Westwood, R. I. (1992). Headship and leadership. In Organisational behaviour: Southeast Asian perspectives (pp. 118-143). Hongkong: Longman.

Yuningsih, N. Y., \& Subekti, V. S. (2016). Demokrasi dalam Pemilihan 
Kepala Desa? Studi Kasus Desa Dengan Tipologi Tradisional, Transisional, dan Modern di Provinsi Jawa Barat Tahun 20082013. Jurnal Politik, 1(2). https://doi.org/10.7454/jp.v1i2.21

Zhao, T. (2018). Vote buying and land takings in China's village elections. Journal of Contemporary China. https://doi.org/10.1080/10670564 .2018 .1389035 